\title{
MANFAAT OLAHRAGA RENANG BAGI LANJUT USIA
}

\author{
Oleh: Ermawan Susanto \\ Dosen Jurusan Pendidikan Olahraga FIK UNY
}

\section{Abstrak}

Secara umum kondisi fisik seseorang yang telah memasuki masa lanjut usia mengalami penurunan. Perubahan-perubahan tersebut pada umumnya mengarah pada kemunduruan kesehatan fisik dan psikis, sehingga secara umum akan berpengaruh pada aktivitas kehidupan sehari-hari. Tulisan ini membahas tentang manfaat olahraga renang dan bentuk latihan renang yang tepat bagi lanjut usia. Tulisan diambil dengan mereview beberapa hasil penelitian dan artikel-artikel olahraga kesehatan khususnya manfaat olahraga renang bagi lanjut usia. Olahraga renang merupakan salah satu olahraga kardiovaskuler (jantung dan pembuluh darah) yang bermanfaat untuk meningkatkan $\mathrm{VO}_{2}$ maks dan penurunan denyut nadi istirahat, yang sebenarnya cocok untuk semua usia khususnya untuk rehabilitasi, terapi, dan lanjut usia. Olahraga renang memiliki peran dalam menyelesaikan berbagai macam permasalahan seperti stres (dalam segi rohaniah) dan juga mampu memberi rangsangan pada tubuh dalam menyembuhkan penyakit (dalam segi jasmaniah). Olahraga renang baik bentuk aktivitasnya maupun media kolam renang, telah berfungsi sebagai terapi kesehatan (bydrotherapy) guna mengatasi masalah-masalah kesehatan seperti bipokinesia (kurang gerak), muskuloskeletal, penyakit dalam, dan masalah psikis. Terdapat sebelas macam bentuk latihan di air yang dapat dilakukan oleh lanjut usia yang dapat meningkatkan status kebugaran jasmani. Namun demikian, dalam melakukan olahraga renang tidak boleh mengalami kelelahan yang berlebihan, bila intensitasnya berlebihan dapat terjadi sesak napas, nyeri dada, atau pusing. Pada lanjut usia olahraga renang dapat dilakukan apabila memperhatikan syarat-syarat keamanannya. Olahraga renang dapat direkomendasikan sebagai olahraga yang aman bagi lanjut usia seperti pada jenis olahraga aerobik lainnya seperti berjalan, bersepeda, atau senam lansia.

Kata Kunci: manfaat renang, lanjut usia, program latiban. 
Penduduk lanjut usia (Lansia) merupakan bagian dari anggota keluarga dan anggota masyarakat yang semakin bertambah jumlahnya sejalan dengan peningkatan usia harapan hidup. Pada tahun 1980 penduduk lanjut usia baru berjumlah 7,7 juta jiwa atau 5,2\% dari seluruh jumlah penduduk. Pada tahun 1990 jumlah penduduk lanjut usia meningkat menjadi 11,3 juta orang atau 8,9\%. Jumlah ini meningkat di seluruh Indonesia menjadi 15,1 juta jiwa pada tahun 2000 atau 7,2\% dari seluruh penduduk. Diperkirakan pada tahun 2020 akan menjadi 29 juta orang atau 11,4\%. Hal ini menunjukkan bahwa penduduk lanjut usia meningkat secara konsisten dari waktu ke waktu. Angka harapan hidup penduduk Indonesia berdasarkan data Biro Pusat Statistik pada tahun 1968 adalah 45,7 tahun, pada tahun 1980: 55.30 tahun, pada tahun 1985: 58,19 tahun, pada tahun 1990: 61,12 tahun, dan tahun 1995: 60,05 tahun serta tahun 2000: 64.05 tahun (BPS, 2000: 1)

Secara umum kondisi fisik seseorang yang telah memasuki masa lanjut usia mengalami penurunan. Hal ini dapat dilihat dari beberapa perubahan: (1) perubahan penampilan pada bagian wajah, tangan, dan kulit, (2) perubahan bagian dalam tubuh, seperti sistem saraf, fungsi organ dalam, (3) perubahan panca indra: penglihatan, pendengaran, penciuman, perasa, dan (4) perubahan motorik, antara lain berkurangnya kekuatan, kecepatan dan belajar keterampilan baru. Perubahan-perubahan tersebut pada umumnya mengarah pada kemunduruan kesehatan fisik dan psikis, sehingga secara umum akan berpengaruh pada aktivitas kehidupan sehari-hari. Masalah umum yang dialami lanjut usia yang berhubungan dengan kesehatan fisik, yaitu berkurangnya daya tahan tubuh dalam menghadapi pengaruh dari luar. Menurut data SKRT (Survey Kesehatan Rumah Tangga) tahun 1980 menunjukkan angka kesakitan penduduk usia 55 tahun ke atas sebesar 25,7\%. Berdasarkan SKRT tahun 1986 angka kesakitan usia 55 tahun 15,1\%, dan SKRT 1995 angka kesakitan usia 45-59 sebesar 11,6\% (Harriyani, 2009: 2). Keadaan di Indonesia juga menunjukkan hal yang sama yaitu ada kenaikan jumlah usia lanjut. Pembangunan di Indonesia memberi dampak adanya perbaikan lingkungan hidup, derajat kesehatan, higiene, dan gizi. Keadaan ini selanjutnya menyebabkan bertambahnya umur harapan hidup, menurunnya angka fertilitas dan mortalitas yang kemudian memberi dampak pada bertambahnya jumlah usia lanjut.

Berbagai penyakit yang secara umum terjadi berhubungan dengan ketuaan antara lain diabetes melitus, hipertensi, jantung koroner, rematik, asma, dan tekanan darah tinggi. (Harriyani, 2009: 4). Penurunan kondisi fisik lanjut usia berpengaruh pada kondisi psikis. Dengan berubahnya penampilan, menurunnya fungsi panca indra menyebabkan lanjut usia merasa rendah diri, mudah tersinggung dan merasa tidak berguna lagi. Dengan adanya penurunan kesehatan dan keterbatasan fisik pada masa lanjut usia maka diperlukan aktivitas jasmani sehari-hari yang ringan, bersifat aerobik, dan yang direkomedasikan untuk lanjut usia. Olahraga renang merupakan salah satu bentuk olahraga yang ringan karena sifatnya aerobik, yang dapat digunakan oleh lanjut usia guna memperoleh kebugaran jasmani. 
Tulisan ini membahas beberapa hasil penelitian dan artikel-artikel tentang olahraga renang bagi lanjut usia. Melihat maksud dari olahraga secara umum, olahraga renang bermanfaat untuk memelihara kesehatan baik jasmani maupun rohani. Olahraga renang dapat dilakukan dengan santai atau menjadi kegiatan rutin yang dapat membawa banyak manfaat bagi tubuh. Olahraga renang dapat mengatasi banyak masalah kehidupan sehari-hari yang berhubungan dengan jasmani, rohani dan sosial.

\section{PEMBAHASAN}

\section{Hakekat Lanjut Usia (Lansia)}

Menurut Undang-undang Nomor 13 tahun 1998 tentang Kesejahteraan Lanjut Usia, yang dimaksud dengan lanjut usia adalah penduduk yang telah mencapai usia 60 tahun ke atas. Diseluruh dunia penduduk Lansia (usia 60 ke atas) tumbuh dengan sangat cepat bahkan tercepat dibanding kelompok usia lainnya. Diperkirakan mulai tahun 2010 akan terjadi ledakan jumlah penduduk lanjut usia. Hasil prediksi menunjukkan bahwa persentase penduduk lanjut usia akan mencapai 9,77\% dari total penduduk pada tahun 2010 dan menjadi $11,34 \%$ pada tahun 2020. Pengertian lanjut usia adalah periode dimana organisme telah mencapai kemasakan dalam ukuran dan fungsi dan juga telah menunjukkan kemunduran sejalan dengan waktu. Ada beberapa pendapat mengenai "usia kemunduran" yaitu ada yang menetapkan 60 tahun, 65 tahun dan 70 tahun. Badan kesehatan dunia (WHO) menetapkan 65 tahun sebagai usia yang menunjukkan proses menua yang berlangsung secara nyata dan seseorang telah disebut lanjut usia (Akhmadi, 2009: 1).

Menua adalah suatu proses menghilangnya secara perlahan-lahan kemampuan jaringan untuk memperbaiki diri atau mengganti diri dan mempertahankan struktur dan fungsi normalnya. Usia lanjut merupakan proses alami yang tidak dapat dihindarkan. Proses menjadi tua disebabkan oleh faktor biologi, berlangsung secara alamiah, terus menerus dan berkelanjutan yang dapat menyebabkan perubahan anatomis, fisiologis, biokemis pada jaringan tubuh dan akhirnya mempengaruhi fungsi, kemampuan badan dan jiwa (Wahyuni, 2008: 2).

Secara alamiah setiap manusia akan menjadi tua atau mengalami proses penuaan. Proses ini tidak dapat dihindari, apapun usaha yang dilakukan. Di Indonesia usia lanjut adalah mereka yang berumur 60 tahun atau lebih dan merupakan kelompok penduduk yang menjadi fokus perhatian para ilmuwan, masyarakat, dan pemerintah belasan tahun terakhir ini. Jumlah usia lanjut terus meningkat baik di Indonesia maupun di dunia dan membawa serta berbagai permasalahan yang harus diantisipasi dan dicarikan jalan keluarnya.

\section{Manfaat Olahraga Renang sebagai Terapi bagi Lanjut Usia}

Berenang adalah olahraga air yang sangat popular dan digemari oleh siapapun karena semua gerakan melibatkan hampir semua otot tubuh, sehingga sangat bermanfaaat bagi 
kesehatan dan menjaga tubuh tetap bugar. Dari zaman batu sura Mesir 2000 SM pada tahun 1538, Nicolas Wynman, seorang profesor bahasa anak Jerman, menulis buku pertama tentang renang. Pertandingan renang di Eropa bermula pada sekitar tahun 1800, kebanyakan menggunakan gaya dada, gaya rangkak depan (crawl), ketika itu di panggil gaya trudgen, diperkenalkan pada tahun 1873 oleh Jhon Arthur Trudgen setelah meniru dari orang-orang asli Amerika. Dalam olahraga renang terdapat banyak teknik dasar yang merupakan unsur penting olahraga renang salah satunya adalah kemampuan untuk meningkatkan $\mathrm{VO}_{2}$ maks dan penurunan denyut nadi istirahat. Olahraga renang merupakan salah satu olahraga kardiovaskuler (jantung dan pembuluh darah). Olahraga ini dapat dilakukan dengan latihan aerobik hanya saja tempatnya di kolam renang, dimana tidak ada ekstra beban terhadap sendi, tulang dan otot. Kondisi dalam air yang tanpa tekanan dapat mengeliminasi cedera yang kadang bisa terjadi pada latihan olahraga di daratan.

Olahraga yang sifatnya aerobik sangat cocok bagi orang-orang yang memiliki masalah dengan persendian, cedera pada tulang, otot, para lansia, ibu hamil. Olahraga ini cocok bagi pemula maupun yang sudah mahir berenang atau yang bukan perenang walaupun tidak mahir dalam berenang, olah raga ini bisa menyebabkan rasa nyaman. Olahraga di dalam air adalah pengalaman menyenangkan karena membuat orang tetap dingin dan rileks serta badanpun tetap fit. Aerobik adalah olahraga yang dilakukan secara terusmenerus dimana kebutuhan oksigen masih dapat dipenuhi tubuh dan kecepatan dalam menempuh waktu. Menurut Garrison, 2001: 27 dua ciri dari latihan aerobik adalah (1) Olahraga tersebut cukup memberikan banyak gerakan tubuh yang mengakibatkan tubuh anda berfungsi untuk janhka waktu sedikitnya 20 sampai 30 menit setiap kali berolahraga, (2) Olahraga tersebut akan memberikan kegiatan yang cukup menarik hingga ingin mengulanginya kembali terus menerus untuk yang akan datang.

$\mathrm{VO}_{2}$ max adalah kemampuan pengambilan oxygen dengan kapasitas maksimal untuk digunakan atau dikonsumsi oleh tubuh selama melakukan exercise maximum. $\mathrm{VO}_{2} \max$ umumnya digunakan sebagai indikator untuk menentukan kemampuan aerobik, dimana kemampuan aerobik akan berkaitan erat dengan system cardio dan system respirasi dalam usaha penyediaan oxygen dan kemampuan untuk menggunakan oxygen tersebut dalam tubuh, sehingga dalam hal ini peran fisioterapi sangat penting dalam memberikan latihan terhadap kebugaran untuk peningkatan $\mathrm{VO}_{2} \mathrm{Max}$. Bentuk latihan yang dapat diberikan kepada fisioterapi terutama latihan yang bertujuan untuk meningkatkan $\mathrm{VO}_{2}$.

Olahraga renang dapat dilakukan oleh siapapun dan efektif untuk meningkatkan derajat kesehatan manusia. Sebaliknya malas berolahraga dengan alasan kurang memiliki waktu dalam jangka panjang dampaknya cukup buruk, yakni munculnya penyakit yang disebabkan oleh bipokinesia (kurang gerak). Di antaranya, tekanan darah tinggi, diabetes melitus, jantung, artritis, dan obesitas. Menurut Albert M. Hutapea (dalam Tamyiz, 2008), dalam bukunya Menuju Gaya Hidup Sehat mengungkapkan, penelitian selama 16 tahun 
terhadap 17.000 alumnus Universitas Harvard menunjukkan, mereka yang tidak aktif berolahraga (yang membakar tidak lebih dari 500 kalori per minggu dalam kegiatan olahraga) lebih cenderung mengidap penyakit jantung.

Berikut ini dijelaskan beberapa manfaat olahraga renang sebagai terapi penyakit dalam yang banyak diderita orang-orang yang malas berolahraga (Tamyiz, 2008: 4-5).

1. Obesitas

Obesitas atau overweight merupakan pemicu segala penyakit. Peningkatan gizi global ternyata menyebabkan epidemi obesitas makin meluas. Latihan fisik berupa olahraga renang ternyata juga dapat menjadi aktivitas untuk membakar kalori. Pembakaran kalori tubuh ternyata tidak selalu ditandai oleh keluarnya keringat. Saat berenang, tubuh akan terasa lebih berat bergerak di dalam air. Otomatis energi yang dibutuhkan pun menjadi lebih tinggi, sehingga dapat secara efektif membakar sekitar $24 \%$ kalori tubuh. Ketika berenang kalori dalam tubuh akan terbakar sehingga secara langsung sangat efektif membakar lemak. Ini tentu sangat membantu anak-anak yang mengalami obesitas di samping perlunya pengaturan pola makan. Jika asupan makanan tidak diatur, mungkin saja olahraga ini tidak jadi melangsingkan, sebab olahraga berenang memicu rasa lapar.

2. Nyeri Sendi

Saat ini, nyeri sendi sering diderita oleh banyak orang. Gaya hidup yang terlalu banyak mendiamkan tubuh mengakibatkan nyeri sendi dibagian tertentu. Misalnya pada lutut dan pergelangan kaki, hal tersebut dapat dialami oleh siapapun. Namun paling rentan terhadap usia dewasa. Oleh sebab itu, dengan berenang dapat menurunkan risiko cedera persendian, terutama di bagian lutut dan pergelangan kaki bagi mereka yang kelebihan berat badan atau mengalami gangguan persendian tulang. Penelitian menunjukkan bahwa berolah raga di dalam air dengan ketinggian sebatas pinggang dapat mengurangi ketegangan sendi hingga 50\%, dan 75\% jika dalamnya air sebatas dada.

3. Kardiovaskular

Salah satu akibat kurang gerak, dapat mengundang berbagai penyakit noninfeksi, di antaranya adalah penyakit kardiovaskular (penyakit jantung, tekanan darah tinggi dan stroke). Hal ini banyak dijumpai pada kelompok usia pertengahan, tua dan lanjut, khususnya yang tidak melakukan olahraga. Berenang sebagai olahraga aerobik yang akan membuat paru-paru sehat, sendi lebih lentur terutama di bagian leher, bahu dan pinggul, karena bagian-bagian tubuh tersebut digerakkan. Meningkatnya kerja dan fungsi jantung, paru-paru dan pembuluh darah ditandai dengan denyut nadi istirahat menurun, kapasitas bertambah, penumpukan asam laktat berkurang, meningkatkan pembuluh darah kolateral, meningkatkan HDL kolestrol, mengurangi aterosklerosis. 
4. Wanita Hamil

Bagi sebagian orang, olah raga sudah menjadi bagian dari gaya hidup. Dengan begitu, bukan alasan bagi wanita hamil untuk tidak atau bahkan malas berolah raga. Jika ditelisik dari sisi medis, renang merupakan olahraga yang banyak diminati oleh mereka yang sedang hamil. Ini lantaran renang memiliki sifat aerobik dan relatif aman dari benturan. Namun, berenang boleh dilakukan oleh ibu hamil asalkan keadaan tubuhnya sehat dan bugar sedangkan air yang menopang berat badan si ibu hamil disinyalir berguna di trimester terakhir kehamilan, untuk memudahkan proses persalinan kelak.

5. Asma

Asma merupakan salah satu masalah kesehatan yang bisa menyebabkan disabilitas (ketidakmampuan) penderita. Serangan asma memang tidak bisa ditebak dan biasanya mendadak. Begitu orang yang menderita asma terkena bahan penyebab alergi, ia pasti langsung susah bernapas. Banyak faktor yang menimbulkan serangan asma misalnya lingkungan, bahan alergen (penyebab alergi), infeksi saluran napas dan polusi udara. Padahal dengan aktivitas berenang serangan asma bisa berkurang. Ini bisa dilakukan oleh orang dewasa maupun anak-anak. Terutama penderita asma yang masih anak-anak, renang sangat dianjurkan, gerakan berirama teratur membantu pola pernapasannya lebih stabil.

6. Masalah Psikis

Olahraga sedikitnya 10 menit setiap hari membuat mental menjadi lebih sehat, pikiran jernih, stres berkurang dan memicu timbulnya perasaan bahagia. Bahwa olahraga membuat peredaran darah menjadi lancar, membakar lemak dan kalori, serta mengurangi risiko darah tinggi dan obesitas merupakan suatu hal yang diketahui umum.

Menurut Daniel Landers (dalam Muchammad Tamyiz, 2008: 6-7), profesor pendidikan olahraga dari Arizona State University mengungkapkan empat manfaat olahraga renang:

1. Meningkatkan kemampuan otak

Latihan fisik yang rutin dapat meningkatkan konsentrasi, kreativitas, dan kesehatan mental. Karena olahraga renang bisa meningkatkan jumlah oksigen dalam darah dan mempercepat aliran darah menuju otak. Hasil penelitian yang telah dipublikasikan Proceeding on the National Academy of Science menyebutkan bahwa manfaat olahraga renang secara benar dan teratur bisa memacu pertumbuhan neuron yang telah rusak.

2. Mengurangi stress

Olahraga dapat mengurangi kegelisahan, bahkan lebih jauh lagi dapat membantu mengendalikan amarah. Latihan aerobik dapat meningkatkan kemampuan 
jantung dan membuat tubuh lebih cepat mengatasi stress. Aktivitas seperti jalan kaki, berenang, bersepeda, dan lari merupakan cara terbaik mengurangi stress

3. Menaikkan daya tahan tubuh

Senang melakukan olahraga meski tak terlalu lama namun sering dengan santai melakukannya, maka aktivitas itu bisa meningkatkan hormon-hormon seperti adrenalin, serotonin, dopamin, dan endorfin. Hormon ini berperan dalam meningkatkan daya tahan tubuh. Para peneliti di Duke University menemukan bahwa $60 \%$ orang depresi yang melakukan olahraga selama empat bulan dengan frekuensi tiga kali seminggu dan setiap latihan selama 30 menit bisa mengatasi gejala ini tanpa obat.

Selain itu pada lanjut usia, osteoporosis bisa sering terjadi. Istilah sederhana osteoporosis berarti tulang keropos atau memiliki masa tulang yang rendah, dan ciri khasnya adalah penurunan masa tulang dan kemunduran jaringan tulang yang menyebabkan tulang mudah patah dan resiko terjadinya fraktur. Sering kali penyakit ini berlangsung tak terdeteksi sampai terjadinya patah tulang oleh karena tabrakan kecil, terjatuh, atau saat berjabat tangan. Untuk mencegah atau mengurangi efek dari osteoporosis adalah dengan menjaga latihan secara rutin. Aktivitas menumpu berat badan (weight-bearing), seperti jalan atau berlari kecil, latihan daya tahan otot, latihan kekuatan otot dapat meningkatkan keseimbangan tubuh, dengan demikian mengurangi resiko terjatuh. Olahraga renang sangat aman untuk latihan bagi penderita osteoporosis. Jenis olahraga di dalam kolam renang ini menyediakan tempat yang aman untuk latihan tanpa menimbulkan risiko terjatuh atau mengalami patah tulang. Olahraga renang meningkatkan kekuatan otot, mengurangi nyeri dengan mengurangi tekanan penumpuan berat badan pada sendi dan tulang, meningkatkan keseimbangan, mempercepat kesembuhan, dan meningkatkan propioseptif (reseptor sendi). Olahraga renang membantu untuk rileks dan meningkatkan sirkulasi darah, lingkup gerak sendi, tonus otot, dan kepercayaan diri (Bates A, \& Hansen N., 1996: 21-28).

\section{Aktivitas Kebugaran Jasmani bagi Lanjut Usia}

Semua jenis olahraga yang pada prinsipnya dapat dilakukan oleh lansia, asalkan jenis olahraga tersebut sudah dikerjakan secara teratur sejak muda. Namun demi keamanan, olahraga yang dianjurkan oleh para ahli adalah olahraga yang sifatnya aerobik, misalnya jalan kaki, senam, dan berenang. Olahraga berenang adalah jenis olahraga yang terbaik, sebab cabang ini memberi resiko cedera paling kecil atau sedikit kemungkinannya cedera. Pada waktu berenang, badan kita terapung, hingga mengurangi tekanan yang berlebihan terhadap persendian dan tulang. Sebelum melakukan latihan olahraga sebaiknya para lansia harus dilakukan tes dan pengukuran yang bertujuan untuk mengukur kebugaran jasmani seseorang. Menurut Irianto (2004: 79) sebelum dilakukan tes kebugaran jasmani ada beberapa syarat yang harus dipatuhi, antara lain sebagai berikut: 
1. Dalam kondisi sehat berdasarkan hasil pemeriksaan dokter.

2. Malam sebelum pengukuran dilakukan, peserta harus cukup tidur (6 jam).

3. Makan terakhir paling tidak 4 jam sebelum pengukuran kebugaran jasmani dilakukan.

4. Sebaiknya mengenakan pakaian dan sepatu olahraga.

5. Pelaksanaan pengukuran sebaiknya pada pagi hari.

Orang yang sudah lanjut usia apabila melakukan olahraga tidak boleh mengalami kelelahan yang berlebihan, bila intensitasnya berlebihan dapat terjadi sesak napas, nyeri dada, atau pusing. Maka kegiatan olahraga harus segera dihentikan. Intensitas olahraga yang boleh dilakukan oleh lansia bersifat individual tergantung pada usia, jenis kelamin, usia awal menekuni olahraga, keteraturan dan kondisi fisik organ-organ tubuhnya. Adapun rumus umum untuk yang dapat digunakan untuk mengetahui batas mana lansia boleh melakukan olahraga, yaitu dengan menentukan denyut nadi maksimal atau dikenal sebagai maksimal pulse. Rumusnya adalah 220-umur. Ambang yang aman adalah, bila aktivitas olahraga hanya mencapai (denyut nadi sub maksimal) $70 \%-85 \%$ dari denyut nadi maksimal yang disebut sebagai target zone. Seseorang dengan umur 70 tahun denyut jantung maksimalnya adalah $220-70=\mathrm{I} 5 \mathrm{O} /$ menit , ia hanya boleh berolahraga sampai denyut nadi sub maksimal, dengan perhitungan $(220-70)$ X 70-85\% = 105- 127 kali permenit.

\section{Tahapan Latihan untuk Kebugaran Jasmani}

Tahapan latihan adalah rangkaian proses dalam setiap latihan, meliputi pemanasan, Kondisioning, dan Penenangan. Tahapan ini dikerjakan secara berurutan:

1. Pemanasan

Pemanasan dilakukan sebelum latihan. Bertujuan menyiapkan fungsi organ tubuh agar mampu menerima pembebanan yang lebih berat pada saat latihan sebenarnya. Penanda bahwa tubuh siap menerima pembebanan antara lain detak jantung telah mencapai $60 \%$ detak jantung maksimal, suhu tubuh naik 1-2 derajat Celsius, dan badan berkeringat. Pemanasan yang dilakukan dengan benar akan mengurangi terjadinya cidera atau kelelahan. (Irianto, 2004: 14)

\section{Kondisioning}

Setelah pemanasan cukup diteruskan tahap kondisioning, yakni melakukan berbagai rangkaian gerak dengan model latihan yang sesuai dengan tujuan program latihan, misalnya jogging untuk meningkatkan daya tahan paru dan jantung atau untuk pembakaran lemak tubuh, latihan stretching untuk meningkatkan kelenturan persendian dan latihan beban untuk kekuatan dan daya tahan otot. Latihan ini kurang lebih berlangsung antara 20 sampai 30 menit, atau disesuaikan dengan tujuan latihan yang dilakukan. Karena latihan ini merupakan latihan kebugaran jasmani sebaiknya berisikan salah satu komponen kebugaran jasmani. 
3. Penenangan

Penenangan merupakan periode yang sangat penting dan esensial. Tahap ini bertujuan untuk: (1) mengembalikan kondisi tubuh seperti sebelum berlatih dengan melakukan serangkaian gerak berupa stretching dan aerobic ringan misalnya jalan di tempat atau jogging ringan. Tahapan ini ditandai dengan menurunnya frekuensi detak jantung, menurunnya suhu tubuh dan semakin berkurangnya keringat, (2) mengembalikan darah ke jantung untuk reoksigenasi, sehingga mencegah genangan darah di otot kaki dan tangan. Lama tahapan ini kira-kira 5 sampai 10 menit.

Berikut ini contoh tiga tipe latihan olahraga bagi lanjut usia diambil dari artikel berjudul Some Effect of Swimming Session for Low-Active Elderly Men (Coleman, 2003).

\section{Three types of exercise for the elderly}

\begin{tabular}{|c|c|c|}
\hline Type of exercise & $\begin{array}{l}\text { Activities recommended } \\
\text { for the elderly }\end{array}$ & Potential benefits \\
\hline Aerobic/endurance & $\begin{array}{l}\text { Walking } \\
\text { Cycling } \\
\text { Aquafit or swimming } \\
\text { Low-impact aerobics }\end{array}$ & $\begin{array}{l}\text { Cardio-respiratory } \\
\text { Weight loss/control } \\
\text { Glycemic control } \\
\text { Pain control } \\
\text { Mood and cognition } \\
\text { Bowels } \\
\text { Sleep }\end{array}$ \\
\hline Resistance/strength & $\begin{array}{l}\text { Free weights } \\
\text { Weight machines } \\
\text { Elastic bands/tubing } \\
\text { Body weight against } \\
\text { gravity }\end{array}$ & $\begin{array}{l}\text { Muscle strength } \\
\text { Bone mass } \\
\text { Physical functioning } \\
\text { Mobility }\end{array}$ \\
\hline Balance and Flexibility & $\begin{array}{l}\text { Stretching } \\
\text { Yoga } \\
\text { Tai-Chi } \\
\text { Stair-climbing } \\
\text { Balance boards, balls, and } \\
\text { elastic bands }\end{array}$ & $\begin{array}{l}\text { Balance } \\
\text { Fall prevention } \\
\text { Mobility } \\
\text { Reaction time }\end{array}$ \\
\hline
\end{tabular}

\section{Program Latihan Renang pada Lanjut Usia}

Untuk mendapatkan keberhasilan program latihan renang bagi lanjut usia perlu ditentukan sarana prasarana terutama kedalaman kolam renang. Ada beberapa kedalaman kolam air yang diprogramkan, yakni 90,120 , dan $180 \mathrm{~cm}$. Bagi lanjut usia dengan keluhan stroke yang baru pertama kali berlatih yaitu dengan berjalan diterapi di kolam dengan kedalaman $90 \mathrm{~cm}$. Kolam dengan kedalaman $120 \mathrm{~cm}$ dan $180 \mathrm{~cm}$ ditujukan untuk pasien yang ingin melatih sendi dan otot-otot menggunakan alat bantu tambahan, seperti dumbel atau bola. Untuk mendapatkan hasil yang signifikan, program latihan dapat dilakukan dengan terapi selama 6-8 minggu, dengan durasi dua kali seminggu, sekali terapi waktunya 1 jam. Gerakan berenang juga akan lebih efektif dan aman jika dilakukan secara perlahan. Awali dengan berenang santai selama 5-10 menit. Setelah itu boleh diulangi dengan jangka waktu yang lebih panjang. 
Frekuensi pun sebaiknya diatur, sekitar 1-2 kali seminggu. Baru setelah tubuh dirasakan bisa beradaptasi dapat meningkatkan intensitas dan frekuensinya sesuai dengan kemampuan. Berenang terbilang minim risiko cedera fisik. Hal ini terjadi karena pada saat berenang seluruh berat badan ditahan oleh air (mengapung). Wajar saja jika berenang kemudian menjadi olahraga yang paling dianjurkan bagi mereka yang kelebihan berat badan (obesitas) dan penderita gangguan persendian tulang atau arthritis.

Namun demikian ada beberapa hal yang tetap harus diperhatikan sebelum, saat, dan setelah berenang. Misalnya, supaya tubuh tidak 'kaget', dianjurkan melakukan gerakan pemanasan dan pendinginan. Mulailah dengan gerakan-gerakan ringan, seperti mengayunkan tangan dan kaki atau berjalan-jalan di sekitar kolam renang selama 1015 menit. Agar bisa mememperoleh manfaat renang, hendaklah berenang dengan benar. Kalau hanya bermain-main dengan air memang menyenangkan, tetapi hal ini hanya melibatkan aktivitas fisik yang sangat rendah dan memberikan efek yang kurang maksimal pada tubuh. Dianjurkan dengan bantuan instruktur renang yang berpengalaman. Hal lain yang perlu diperhatikan ialah keamanan tempat renang demi kesehatan, karena pada orang tertentu kejadian sakit akan lebih sering bila berenang. Perhatikan juga kualitas air, misalnya kejernihan, derajat-keasaman $(\mathrm{pH})$ antara $10-11 \mathrm{pH}$, bahkan polusi, yang bisa saja dapat mengganggu kesehatan.

Hal-hal di atas perlu diperhatikan agar mendapatkan manfaat dari olahraga renang secara maksimal. Berikut ini disajikan bentuk-bentuk latihan air yang bisa dilakukan: 1. Jalan di air atau water jogging yaitu dengan menggunakan beberapa langkah dan gerakan lengan di dalam air.

2. Aerobik air yaitu gerakan ritmik seluruh badan selama 20 menit atau lebih di tempat dangkal atau dalam air. Tujuannya adalah untuk daya tahan jantung paru.

3. Latihan penguatan air yaitu gerakan atas dan bawah badan dengan menggunakan ketahanan air dan atau perlengkapan untuk memperkuat dan membentuk otot.

4. Latihan kelenturan yaitu gerakan yang luas dengan menggunakan seluruh gerakan dan rentangan badan yang penuh.

5. Terapi air dan rehabilitasi yaitu adalah prosedur di air yang diterapkan untuk tujuan kesehatan tertentu.

6. Yoga air dan relaksasi yaitu gerakan mengapung yang mudah dengan air sebagai media relaksasi.

7. Latihan di air yang dalam merupakan gerakan-gerakan di air yang dilakukan dimana kaki tidak menyentuh dasar kolam. Jaket pengapung sebaiknya digunakan.

8. Jogging atau berlari di air yang dalam simulasi jogging di daratan dan berlari di kolam dangkal digunakan dengan berulang-ulang.

9. Latihan dinding menggunakan dinding kolam renang untuk mendukung perlindungan berbagai bagian badan. 
10. Stretcbing adalah gerakan pelan khusus yang digunakan setelah pemanasan dan pada akhir latihan untuk mengulur otot-otot badan yang telah bekerja keras dan menolong dari cedera.

11. Renang berjarak ialah berenang dengan memilih berbagai gaya renang yang ada dengan berbagai macam teknik merupakan salah satu pilihan kebugaran.

\section{KESIMPULAN}

Olahraga renang selain berfungsi sebagai rekreasi, juga berfungsi sebagai sarana terapi bagi masalah-masalah kesehatan. Pada kelompok lanjut usia, renang dapat dilakukan apabila memperhatikan syarat-syarat keamanannya. Manfaat yang diperoleh dari olahraga renang bagi kelompok lanjut usia adalah untuk menjaga kebugaran jasmani sekaligus merehabilitasi beberapa gangguan fungsi tubuh. Dengan demikian pada kelompok lanjut usia diharapkan dapat melaksanakan kegiatan sehari-hari dengan optimal. Hal ini berbeda dengan pendapat umum di masyarakat bahwa lanjut usia sebaiknya banyak istirahat, diam, tidak banyak kerja, dan tidak boleh berolahraga. Dengan mengetahui dan memahami renang, dapat meningkatkan pemahaman yang lebih dalam tentang manfaat olahraga renang.

\section{DAFTAR PUSTAKA}

Akhmadi. (2009). Permasalahan pada Lanjut Usia (Lansia). http://www.blog.akhmadi.com. Bates A, \& Hansen N. (1996). The Principles and Properties of Water: Aquatic Exercise and Therapy. Philadelphia, PA: WB Saunders Co.

Biro Pusat Statistik. (2000). Angka Harapan Hidup Penduduk Indonesia. Jakarta.

Coleman, Veronique. (2003). "Some Effect of Swimming Session for Low-Active Elderly Men" Article published in: Proceedings of International symposium on Biomechanics and Medicine in Swimming, St. Etienne 2003

Darmojo, B. (1999). Geriatri (Ilmu Kesehatan Usia Lanjut). Jakarta: Balai Penerbit Fakultas Kedokteran Universitas Indonesia.

Garrison, Susan J. (2001). Dasar-dasar Terapi dan Rehabilitasi Fisik. Alih Bahasa: dr. Anton Cahaya Widjaja. Jakarta: Hipokrates Publisher.

Harriyani, Novita Ludvy. (2009). "Perbedaan Pengaruh Latihan Lari Aerobik dan Latihan Renang terhadap Peningkatan Kebugaran”. Skripsi. Surakarta. Fakultas Ilmu Kesehatan Universitas Muhammadiyah Surakarta.

Irianto, Djoko Pekik. (2004). Pedoman Praktis Berolabraga untuk Kebugaran dan Kesehatan. Yogyakarta: Andi Offset.

Tamyiz, Muhammad. (2008). Olahraga Renang sebagai Terapi Penyakit Dalam. http:// www.blog.muchammadtamyiz.com. 
Undang-undang RI Nomor 13 tahun 1998 tentang Kesejahteraan Lanjut Usia. Jakarta. Wahyuni (2008). Perbedaan Pengaruh Senam Otak dan Senam Lansia terhadap Keseimbangan pada Orang Lanjut Usia. Jurnal Infokes Vol 8 No 1 MaretSeptember 2004. [Online]: Http://www.jurnalinfokes.com/wahyuni. 